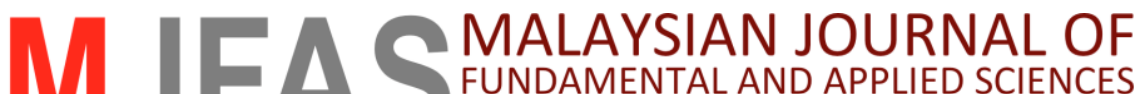

\section{Emerging of cardiovascular metal stent: A review on drug-eluting stent towards the utilisation of herbal coating}

\author{
Siti Khadijah Lukman a, Rania Hussien Al-Ashwal a, Ahmad Zahran Md. Khudzari a, b, Syafiqah \\ Saidin a, b, \\ a School of Biomedical Engineering \& Health Sciences, Faculty of Engineering, Universiti Teknologi Malaysia, 81310 UTM Johor Bahru, Johor, \\ Malaysia. \\ b IJN-UTM Cardiovascular Engineering Centre, Institute of Human Centered Engineering, Universiti Teknologi Malaysia, 81310 UTM Johor Bahru, \\ Johor, Malaysia \\ * Corresponding author: syafiqahsaidin@biomedical.utm.my
}

\section{Article history}

Received 13 April 2018

Revised 8 September 2018

Accepted 31 December 2018

Published Online 14 April 2019

\begin{abstract}
Metal stents used in the treatment of percutaneous coronary intervention $(\mathrm{PCl})$ have revolutionized in treating atherosclerosis disease. Starting from the emergence of bare metal stent (BMS), this stent has been progressively developed into drug-eluting stent (DES) and biodegradable stent. By focusing on DES, various drugs have been used to coat metal stent with the aims to overcome instent restenosis and stent thrombosis. Therefore, the utilisation of various drugs and polymers as coating materials was reviewed in this study to identify possible alternative to overcome the current DES problems. Even though, both complications of BMS are covered successfully by DES, however, DES projects long term complications of delayed endotheliasation, delayed wound healing and late stent thrombosis. Another alternative of herb coating on DES is considered to be a potential approach in improving endotheliasation and retarding smooth muscle cells proliferation to accelerate wound healing and to prevent late stent thrombosis.
\end{abstract}

Keywords: Metal stent, drug-eluting stent, drug coating, cardiovascular

\section{INTRODUCTION}

Cardiovascular disease (CVD) is a disease related to heart and blood vessel caused by atherosclerosis that is affecting the entire arterial circulation related to pathologic process [1]. Atherosclerosis is a build-up of plaque and fatty deposits, cellular debris and cholesterol, leads to narrowing of blood vessels [2]. This disease is the leading cause of death in the world and surpasses the number of death, caused by other diseases such as acquired immunodeficiency syndrome (AIDS) and cancer [3]. There are several risk factors that contribute to CVD such as obesity, hypertension, diabetes and smoking [1]. In, 2013, CVD has projected more than 17.3 million deaths per year and depicting $31 \%$ of all global death [4]. This statistic is presumed to increase gradually, up to more than 23.6 million by 2030 [4].

In Malaysia, CVD has led to mortality and morbidity of $36 \%$ of total deaths in 2014 [5]. Therefore, preventions must be taken aggressively and more affordable treatments should be offered to aid the increasing number of CVD cases. A coronary artery bypass graft or a less invasive technique called percutaneous coronary intervention (PCI) is a common treatment used to remove the blockage of narrowing arteries [2]. Percutaneous coronary intervention, sometimes called angioplasty is frequently performed as a treatment for atherosclerotic lesions in the coronary artery and usually involves balloon angioplasty and stent implantation [6].

Stents have been developed rapidly through many years from the evolvement of bare metal stent (BMS) to drug-eluting stent (DES) and biodegradable stent [6]. Various types of drug are used as coating materials to overcome the limitation of BMS where this type of stent is known as DES [6]. However, DES also has long term complications such as late endotheliasation, delayed wound healing and late stent thrombosis [7]. Therefore, the aim of this paper was to provide a review on the utilisation of various drugs as coating materials in identifying possible alternative to overcome the current complications of DES. The review was divided into three sections: Stent; Commercial drug coating on DES; Herb coating on DES for cardiovascular application. In the first section, elaboration on revolution and types of stent were provided while in the second section, current commercial drugs which are being used as coating materials on DES were discussed to express the main constraint of commercial DES. In the third section, several herbs with specific therapeutic benefit, that have potential to be used in DES fabrication were presented and the final review was focused on ginseng due to its dual therapeutic functions.

\section{Stent}

Stent is a metal wire mesh, used in PCI treatment which requires elasticity and strength to support arterial walls in reducing the chance of narrowing arteries by keeping the lumen clear from plaque development [8-10]. With diameter from 1.5 to $3.0 \mathrm{~mm}$ and 15 to 30 $\mathrm{mm}$ long [11], it is also acts as a temporary or permanent vascular scaffold, preventing restenosis and incidence of acute vessel blockage after dissection as compared with plain old balloon angioplasty (POBA) [12]. During PCI treatment, a stent is inserted along with balloon catheter to the afflicted coronary artery before it is expanding to constrict atherosclerotic plaque [13]. As the balloon catheter is inflated and withdrawn from the body, the expanded stent remains in 
the artery to support the weak arterial wall. In 1964, the first angioplasty was introduced by Charles Theodore Dotter and Melvin P. Judkins [14] followed by placement of the first coronary angioplasty during a coronary artery bypass graft surgery, performed by Gruentzig and Myler in May 1977 [6]. Four months later, on 16 September 1977, Andreas Gruentzig performed the first PCI in an awake patient which has been marked as a revolution in interventional cardiology $[6$, $15,16]$.

Coronary stent was primarily introduced in the mid-1980s [14], acts as a vascular scaffold. It has ousted the POBA as a favoured method for PCI treatment, after successful observation on angiographic and clinical outcomes [14]. The utilisation of coronary stents is revolutionised with major refinements in stent design and composition [6]. Implantation of the first coronary BMS was performed by Jacques Puel in Toulouse [17] where restenosis rate was relatively decreased to $15-30 \%$ [3]. Coronary stent implantation was then announced as a standard procedure by National Institute for Health and Care Excellence (NICE) in the United Kingdom in May 2000 for treating patients suffering from myocardial infarction [3]. Fig. 1 illustrates the evolution of cardiovascular metal stent in treating CVD.
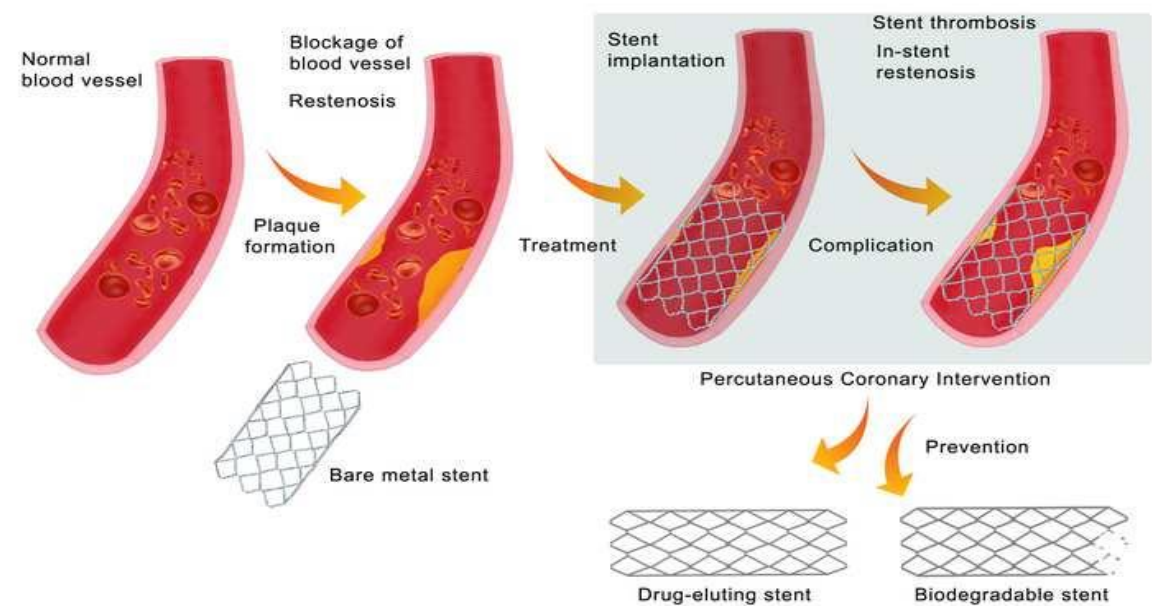

Fig. 1 Illustration of evolution of cardiovascular metal stent in treating CVD.

\section{Bare metal stent (BMS)}

Bare metal stent is made of metallic materials such as stainless steel, cobalt-chromium, nitinol, etc, established to reduce restenosis caused by vascular recoil and to overcome complications after dissection [18]. The implantation of BMS is involving several procedures. Catheter consists of an inflatable balloon is inserted into the artery through a skin cut with a stent, fixed at the end part of the balloon [19]. A radial force exerts on the stenotic blood vessel due to dilatation of the stent. The stent stays in place and resists contraction of the blood vessel caused by permanent deformation [19].

The restenosis rate was successfully reduced by stent implantation, however, an in-stent restenosis (ISR) becomes the forthcoming problem with an occurrence of $20-35 \%$ [11, 20-21]. In a failure case, these neointima tissues that enclosed a stent once the stent is implanted into the vessel, proliferate extremely and clog the vessel that later trigger hyperplasia [19]. Besides, BMS is also regarded as a foreign material that becomes the site of origin for blood clot formation and localized inflammation [9]. A profound fibrotic response and late lumen damage are another complications of BMS where it can reduce arterial diameter by $800 \mathrm{~mm}$ due to development of $400 \mathrm{~mm}$ thick layer of fibrotic tissues within the stent [22].

\section{Drug-eluting stent (DES)}

Introduction of DES is specifically to overcome the ISR. Drugeluting stent is a drug-coated stent which functioned to accommodate drugs and to regulate drug release into surrounding tissues [8]. It has brought effectively advancement in the management of coronary vessel revascularisation. It has also deducted the occurrence of major cardiac events from $16.4 \%$ (BMS implantation) to $7.8 \%$ (DES implantation) [23]. Moreover, DES has inhibited the growth of neointimal by releasing an anti-proliferative drug locally, thus maintaining vascular patency [24]. Despite of its advantage, DES also has limitations in long-term adverse clinical events such as late thrombosis, poor vascular endotheliasation, local hypersensitivity and delayed wound healing [24].

Drug-eluting stent can be divided into three different groups based on its structure [25]: 1) Membrane covered stents, where a membrane loaded with drug is coated over a stent. The membrane controls the release of incorporated drugs into adjacent tissues and minimises loss of drug along the lumen when it is only bared to the vessel epithelium.
However, due to limited anchoring strength at the site of implantation, the membrane-covered stent has higher rate of movement in the blood vessel. Besides, mechanical properties of the stents are still diminished, in longitudinal direction including its flexibility, extension capability and collapse pressure.

2) Drug-reservoirs based stents, where drugs or drug/polymer mixture are filled in different shapes of drug reservoirs that are formed within the stent struts. The main advantage of this type of DES, is the ability to control drug distribution at implantation site by changing reservoir design and quantity of drug inside the reservoir. However, intricate approaches are needed to form reservoirs within the tiny structure of stent struts and to incorporate drug into the reservoirs. 3) Layer-coated stents, where stent struts are coated with a thin layer of drug integrated carrier. This type of DES has exceptional mechanical properties compared to the membrane-covered stents. However, the drug is washed away from the action site when this monolithic coating layer is exposed to blood stream through the lumen.

All these scenario lead to the development of DES with an intention to restrain ISR and neointimal proliferation [26]. Besides, requirement for repetition of interventions is reduced and the coronary arteries also remain open for lengthy time after the implantation of DES [13]. Although DES showed exceptional performance, however, late thrombosis and restenosis are still arisen following DES implantation [27, 28]. These problems are possibly caused by long haul impact of polymer, holding the stent while delivering drug into the arterial wall [26]. Another factor is lies on the inability of endothelisation around the vessel wall [2].

\section{Biodegradable stent}

Until the vessel remodels and heals, a biodegradable stent is projected to open narrowed blood vessel temporarily before degraded progressively [29]. Biodegradable stent is forecasting to restore blood flow and to provide mechanical support temporarily to prevent vessel recoil [30, 31]. Besides, it needs to possess certain point of fracture toughness and sustained deformations in avoiding broken struts or fragmentation following implantation [31,32]. The materials must be able to degrade following gradual resorption that match with the healing period of blood vessel where inflammatory responses and tissue overload should not be provoked by the degradation release 
[31]. Great biocompatibility, good fatigue and physical resistance to aging, ability to withstand high-temperature heat processing, highenergy laser cutting and critical sterilisation conditions are other necessary features required by the materials [31].

Bioactive stents like DES are notably known for its great achievement in curing patients with coronary artery disease. However, they still have flaws in long-term repercussion [13]. Therefore, clinicians mostly believe that stent is required to reinforce mechanical structure of vessel wall transiently during the remedial period as the healing of the artery is between 3 and 6 months following stent implantation [13]. The possibility of late complications such as restenosis and thrombosis due to the placement of permanent device can be avoided with utilisation of temporary device that degrades after certain period [13].

Biodegradable implant offers more than permanent metallic implants in terms of physiological reconstruction, reconstitution of local vascular compliance, and a brief, limited, longitudinal, and radial straightening effects including the probability of growth [33]. Materials used in the development of biodegradable stents are polymers and metals: either magnesium or iron-based [29, 34]. Biodegradable polymers have promising properties to serve as a biodegradable implants, however severe inflammation is recorded following implantation due to their degradation products. Its slow expansion in blood could cause injuries to the blood vessel [35]. As for magnesium alloy, it has high mechanical properties compared to polymer but it dissolves too fast to match the clinical requirements of cardiovascular application [35].

\section{Commercial drug coating on drug-eluting stent}

There are several drugs have been incorporated within polymers as a coating material on DES. Two types of commercialised drugs commonly used to coat stents are "limus" family and cancer chemotherapy drug paclitaxel [22].

The first generation of DES using sirolimus and paclitaxel hinder restenosis by suppressing production of smooth muscle cell, however, late stent thrombosis is still occur following the implantation [11]. The second generation of DES is the utilisation of sirolimus derivatives including everolimus, zotarolimus and biolimus [36-38, 11]. They revamped clinical results of repeat revascularisation, myocardial infarction and stent thrombosis $[39,40]$. However, burst release of drugs bombarding the occurrence of thrombosis despite of their advantages.

Sirolimus or also known as Rapamycin is a novel immunosuppressive agent that can interrupt the pathway of vascular endothelium growth factor (VEGF) and limiting tumor production to avoid angiogenesis [41]. It has been approved by Food and Drug Administration (FDA) as a primary immunosuppressant due to its antiproliferative property and its strong anti-rejection effects that reduces cardiac allograft vasculopathy and absence of toxicity in the kidneys in cardiac transplant patients [42]. A comparison by Park et al. [43] showed that cell viability of rabbit iliac artery on tacrolimuseluting stent with biodegradable polymer, sirolimus-eluting stent and everolimus-eluting stent were reduced in a dose-dependent manner where all drugs inhibited smooth muscle cell proliferation. However, the growth of endothelial cells was retarded in the treatment with the tacrolimus compared to the sirolimus and everolimus [43]. Significant different in fibrin score was also reported where the tacrolimus group demonstrated better score than the sirolimus and everolimus [43].

Yazdani et al. [44] evaluated coating integrity as a function of time in their in vivo studies by comparing several commercial available DES: Xience prime everolimus-eluting stent, Resolute zotarolimus-eluting Stent, Taxus paclitaxel-eluting stent and Nobori biolimus A9-eluting stent. The everolimus and zotarolimus types of DES have less coating deformity than the paclitaxel and biolimus A9 where coating defect was not observed on most struts [44]. Only a few struts of the everolimus type of DES showed minor defects and for the zotarolimus type of DES, the struts showed no coating defects at all time points except at 180 days [44]. However, webbing and uneven coating were noticed on the paclitaxel struts while polymer cracking appeared on majority of the biolimus A9 struts [44].

In a work by Stone et al. [45], a comparison was done on patients with ST-segment elevation, suffered from myocardial infarction where the disease was treated with paclitaxel-eluting stents and BMS. Through international, prospective and controlled trials, the rate of angiographic restenosis was significantly decreased [45]. The rate of recurrent ischemia required repeat revascularisation method in paclitaxel-eluting stent treatment wal also decreased, compared with the patients who received BMS within the first year [45]. On the other work by Jazi et al. [46], they investigated the effects of implantation of BMS and DES on circulating endothelial cells. The studies were performed in 22 patients suffered from PCI where the amount of cell which acted as cellular markers of endothelial dysfunction following PCI was determined, before and after a week of stent implantation [46]. The circulating endothelial cells count in the DES group was significantly lower compared to the BMS group after one week of stent implantation. This finding demonstrated lower endothelial injury after the DES implantation.

Table 1 summarise the previous studies on commercial drug coating for DES fabrication which consists of everolimus, zotarolimus, paclitaxel, biolimus, sirolimus and tacrolimus. From these review, the main constraint of the commercial DES is lying on the post-implantation scenario of lack endotheliasation and delayed wound healing. Therefore, a review on the utilisation of herb as coating materials was done due to its promising values in promoting proliferation of endothelial cells and inhibiting differentiation of smooth muscle cells to prevent late stent thrombosis.

Table 1 Summary of previous studies on commercial drug coating for DES fabrication.

\begin{tabular}{|c|c|c|c|c|}
\hline $\begin{array}{l}\text { Authors, } \\
\text { Year }\end{array}$ & DES & Drug category & Review Summary & $\begin{array}{l}\text { Referenc } \\
\mathrm{e}\end{array}$ \\
\hline $\begin{array}{l}\text { Yazdani et } \\
\text { al., } 2016\end{array}$ & $\begin{array}{l}\text { Xience prime everolimus- } \\
\text { eluting stent, Resolute } \\
\text { zotarolimus-eluting stent, } \\
\text { Taxus paclitaxel-eluting } \\
\text { stent and Nobori biolimus } \\
\text { A9-eluting stent }\end{array}$ & $\begin{array}{l}\text { Everolimus, } \\
\text { zotarolimus, } \\
\text { paclitaxel } \\
\text { and biolimus A9 }\end{array}$ & $\begin{array}{l}\text { Less coating deformity on everolimus and zotarolimus type of } \\
\text { DES. Minor defects on a few struts of everolimus type of DES and } \\
\text { no coating defect on zotarolimus type of DES at all time points } \\
\text { except at } 180 \text { days of analysis. Webbing and uneven coating on } \\
\text { paclitaxel struts and polymer cracking on majority of biolimus A9 } \\
\text { struts. }\end{array}$ & {$[44]$} \\
\hline $\begin{array}{l}\text { Park et al., } \\
2015\end{array}$ & $\begin{array}{l}\text { Tacrolimus-eluting stent, } \\
\text { sirolimus-eluting stent and } \\
\text { everolimus-eluting stent }\end{array}$ & $\begin{array}{l}\text { Tacrolimus, } \\
\text { sirolimus } \\
\text { and everolimus }\end{array}$ & $\begin{array}{l}\text { Decrement viability of smooth muscle cells in rabbit iliac artery for } \\
\text { all groups in dose-dependent manner. Growth retardation of } \\
\text { endothelial cells and higher fibrin score on tacrolimus group } \\
\text { compared to sirolimus and everolimus groups. }\end{array}$ & [43] \\
\hline $\begin{array}{l}\text { Jazi et al., } \\
2011\end{array}$ & $\begin{array}{l}\text { Sirolimus-eluting stent } \\
\text { (Cypher) and paclitaxel- } \\
\text { eluting stent (Taxus) }\end{array}$ & $\begin{array}{l}\text { Sirolimus } \\
\text { and paclitaxel }\end{array}$ & $\begin{array}{l}\text { Lower count of endothelial cells on sirolimus and paclitaxel groups } \\
\text { compared to BMS or non-coating stent after one week of } \\
\text { implantation }\end{array}$ & [46] \\
\hline $\begin{array}{l}\text { Stone et } \\
\text { al., } 2009\end{array}$ & Paclitaxel-eluting stent & Paclitaxel & $\begin{array}{l}\text { Lower rate of angiographic restenosis and lower rate of recurrent } \\
\text { ischemia on paclitaxel group compared to BMS or non-coating } \\
\text { stent. }\end{array}$ & [45] \\
\hline
\end{tabular}




\section{Herb coating on des for cardiovascular application}

Several herbs (Fig. 2) have been incorporated within polymers for the purpose of stent coating. For example, a purified compound of Chinese herb medicine, Tripterygium wilfordii or known as Triptolide has shown anti-proliferative effect through in vivo and in vitro analyses. It has an ability to suppress the proliferation of vascular smooth muscle cells, inactivates the pathway of mitogen-activated protein kinase (MAPK), modulates the protein cycle of p21cip1 cell and reduces the phosphorylation of retinoblasma protein [47]. The triptolide-coated stent also displayed attenuation of neointimal formation compared to the BMS after one month of implantation [47]. In a study by Lee et al. [48], they mixed water extractions derived from eight herbal plants of Pinellia ternate Ten. Ex Breitenb., Atractylodes macrocephala Koidz., Gastrodia elata Blume, Citrus unshiu Marcow., Poria cocos Wolf, Crataegus pinnatifida Bunge var. typica C. K. Schneider, Siegesbeckia pubescens Makino. and Coptidis japonica Makino to be coated on stent. They notably found reduction in restenosis, retardation of neointimal hyperplasia and inhibition of smooth muscle cell growth [48]. However, high dose of these herbal plants has slightly increased the toxicity of the samples in their animal study [48].

Karki et al. [49] administrated ethanolic extract of Magnolia Cortex (MOE) orally on intimal tissues in rat carotid artery caused by balloon endothelial denudation. They expressed that the MOE extract which was originated from Magnoliaceae has therapeutic potential in the setting of vascular injury as they successfully inhibited the migration of smooth muscle cell and suppressed intimal thickening in rat carotid artery. In another study, Zulaika et al. [50] worked on the development of poly(lactic-co-glycolic acid) (PLGA) and ginsenoside coating on stainless steel 316L (SS316L) substrates using a dip coating technique as a possible alternative to solve the current problems of late restenosis and poor endotheliasation. However, further investigation on the ability of the PLGA/ginseng coated stent should be carried out as they are presumed can retard the growth of smooth muscle cells and promote the proliferation of endothelial cells. Table 2 summarise the previous findings on herbs coating on DES.

Table 2 Summary of previous studies on herb coating which possibly be used for DES fabrication.

\begin{tabular}{|c|c|c|c|}
\hline $\begin{array}{l}\text { Authors, } \\
\text { Year }\end{array}$ & Herbs Coating & Review Summary & $\begin{array}{l}\text { Referen } \\
\text { ce }\end{array}$ \\
\hline $\begin{array}{l}\text { Tao et al., } \\
2011\end{array}$ & Triptolide (Tripterygium wilfordii) & $\begin{array}{l}\text { Suppress proliferation of vascular smooth muscle cells, } \\
\text { inactivate mitogen-activated protein kinase (MAPK) pathway, } \\
\text { modulate protein cycle of p21cip1 cell and reduce } \\
\text { phosphorylation of retinoblasma protein and attenuate } \\
\text { neointimal formation compared to BMS or non-coated stent } \\
\text { after one month of implantation. }\end{array}$ & [47] \\
\hline $\begin{array}{l}\text { Lee et al., } \\
2011\end{array}$ & $\begin{array}{l}\text { Water extractions of eight herbal plants (Pinellia } \\
\text { ternate Ten. Ex Breitenb., Atractylodes } \\
\text { macrocephala Koidz., Gastrodia elata Blume, } \\
\text { Citrus unshiu Marcow., Poria cocos Wolf, } \\
\text { Crataegus pinnatifida Bunge var. typica C. K. } \\
\text { Schneider, Siegesbeckia pubescens Makino., and } \\
\text { Coptidis japonica Makino) }\end{array}$ & $\begin{array}{l}\text { Reduce restenosis, retard neointimal hyperplasia and inhibit } \\
\text { smooth muscle cell growth. Increase toxicity at high dose of } \\
\text { water extractions. }\end{array}$ & [48] \\
\hline $\begin{array}{l}\text { Karki et al., } \\
2012\end{array}$ & Ethanolic extract of Magnolia Cortex (MOE) & $\begin{array}{l}\text { Inhibit migration of smooth muscle cells and suppress intimal } \\
\text { thickening in rat carotid artery. }\end{array}$ & [49] \\
\hline
\end{tabular}

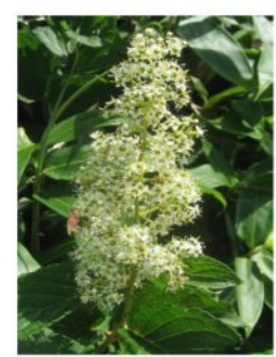

Tripterygium wilfordii

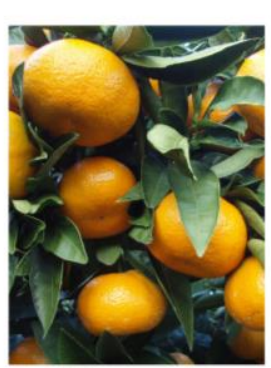

Citrus unshiu Marcow

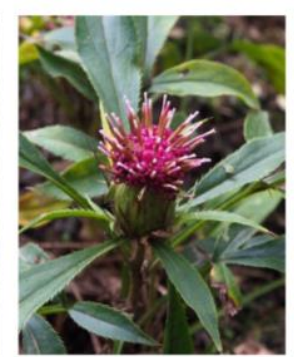

Atractylodes macrocephala Koidz

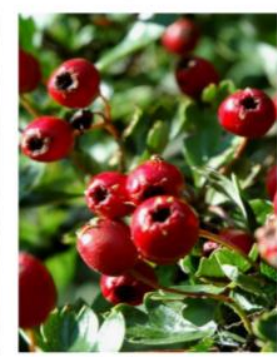

Crataegus pinnatifida Bunge var. typica C. K. Schneider

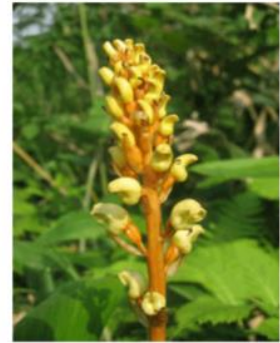

Gastrodia elata Blume

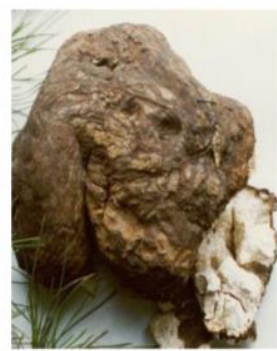

Poria cocos Wolf

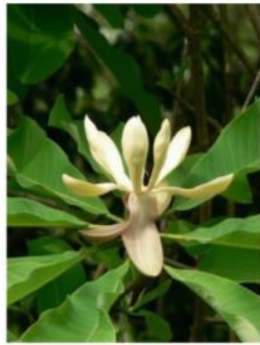

Magnolia Cortex

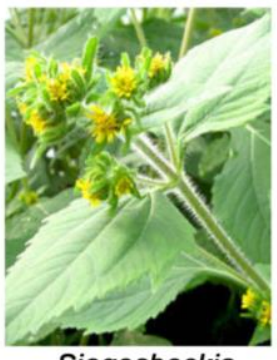

Siegesbeckia pubescens Makino

Fig. 2 Potential herbs that can be used for DES coating.

\section{Ginseng in cardiovascular application}

Ginseng is one of the herb plants that has been used as an alternative remedy since years ago by the people in Eastern Asia Countries [51]. People believes that ginseng can cure illness and relieves stressful lifestyle [52]. Panax ginseng is belonged to ivy family of Araliaceae [53] and it is widely used in Asian countries to keep the body homeostasis constant and strengthen the vital energy [54]. Panax ginseng can be divided into two types which are red 
ginseng and white ginseng. Ginsenosides are the main active ingredients inside the ginseng, accounted at least 30 different ginsenosides, extracted from the roots, stems or leaves of Panax ginseng [55]. It has been reported that ginsenosides confer many positive impacts to cardiovascular system [56-59]. Based on the structure of aglycon with a dammarane skeleton, ginsenosides can be divided into three different categories which are protopanaxadiol (PPD), protopanaxatriol (PPT) and oleanane saponins [60]. The PPDand PPT- type ginsenosides are further classified into several subgroups based on the position and number of sugar moieties attached to the aglycon at positions C3 or C6 and C20 [60]. Qin et al. [55] reported that the administration of total ginsenosides has suppressed monocrotaline (MCT)-induced pulmonary hypertension, an established model similar to human pulmonary hypertension. Total ginsenosides has significantly decreased full term right ventricular systolic pressure, right ventricular hypertrophy index and lung weight/body weight in the MCT-induced pulmonary hypertension, indicating protective impact on pulmonary hypertension given by the total ginsenosides where these results were obtained from the assessment of right ventricular systolic pressure and right ventricular hyperthropy index.

Furthermore, $\mathrm{Zu}$ et al. [61] verified the protective effect of $\mathrm{Rg} 1$ ginsenoside on intestinal ischemia/reperfusion or hypoxia/ reoxygenation by activating the pathway of Wnt/ $\beta$-catenin, suppressing apoptosis and inhibiting the production of reactive oxygen species [61]. The effect of Korean Red Ginseng extract (KRGE) also has been tested on apoptosis of human umbilical vein endothelial cells (HUVECs) in a serum-deprived apoptosis model [62]. The KRGE inhibited serum deprivation-induced apoptotic cell death in the HUVECs and displayed protective effect higher than the American Ginseng extract (AGE). The KRGE also has an antiapoptotic property to prevent endothelial cell death [62]. Interestingly, it has an ability to retard tumor cells when tested on anticancer drug cisplatin-induced HeLa cells [62]. Ginsenoside Rc is one of the compositions in Panax ginseng that exhibit anti-cancer, antiinflammatory, anti-obesity and anti-diabetic effects. As shown in a flow cytometric analysis, ginsenoside Rc mediates strong antiinflammatory activity by blocking Tumor Necrosis Factor- $\alpha$ (TNF- $\alpha$ ) expression in synovial cells, where TNF- $\alpha$ is a pro-inflammatory cytokine that develops rheumatoid arthritis [63].

\section{Ginseng coating on drug-eluting stent}

Anti-proliferative and anti-thrombotic properties are among crucial characteristics required for the development of DES. Both properties demonstrate the ability of DES to inhibit the proliferation of vascular smooth muscle cells and to promote the proliferation of endothelial cells specifically to overcome recent problems of DES such as poor endotheliasation, ISR and late thrombosis. In our previous research, we have successfully incorporated ginsenosides $\operatorname{Rg} 1$ and Re with PLGA as a coating material on metallic stent using a dip coating technique [49]. However, the theory to retard the proliferation of vascular smooth muscle cells and to induce the growth of endothelial cells are remain unknown for ginseng coated stent. Further analyses are needed to investigate the potential of this stent to express their function as DES. Several other techniques also should be explored to develop a stable herbal based drug-eluting coating on metallic stent that possess optimum characters to function as DES.

\section{CONCLUSION}

Stent used in PCI has revolutionized over years in the treatment of atherosclerosis, starting from BMS, DES and biodegradable stent. Various drugs such as sirolimus, its derivatives and paclitaxel have been used as coating materials on DES to overcome restenosis and stent thrombosis. However, long term complications of delayed endotheliasation, delayed wound healing and late stent thrombosis become an obstacle in the implantation of DES. Therefore, providing a new strategy is an attempt to combat these problems. The utilisation of herbs as coating materials should be considered to be a possible way to reduce the current DES complications.

\section{ACKNOWLEDGEMENT}

The authors would like to acknowledge a financial support from the Transdisciplinary Research Grant (TRGS), no. R.J130000.7845.4L843 given by Malaysian Ministry of Higher Education (MOHE).

\section{REFERENCES}

[1] Maulik, N. (2013) Cardiovascular diseases: Nutritional and therapeutic interventions. Florida: CRC Press.

[2] Tan, A., Farhatnia, Y., de Mel, A., Rajadas, J., Alavijeh, M. S., \& Seifalian, A. M. (2013). Inception to actualization: Next generation coronary stent coatings incorporating nanotechnology. Journal of Biotechnology. 164(1), 151-170.

[3] Simsekyilmaz, S., Liehn, E. A., Militaru, C., \& Vogt, F. (2015). Progress in interventional cardiology: challenges for the future. Thrombosis and Haemostasis, 113(3), 464-472.

[4] Mozaffarian, D., Benjamin, E. J., Go, A. S., Arnett, D. K., Blaha, M. J., Cushman, M., Das, S. R, de Ferranti, S., Després, J. -P., Fullerton, H. J., Howard, V. J., Huffman, M. D., Isasi, C. R., Jiménez, M. K., Judd, S. E., Kissela, B. M., Lichtman, J. H., Lisabeth, L. D., Liu, S., Mackey, R. H., Magid, D. J., McGuire, D. K., MohlerIII, E. R., Moy, C. S., Muntner, P., Mussolino, M. E., Nasir, K., Neumar, R. W., Nichol, G., Palaniappan, L., Pandey, D. K., Reeves, M. J., Rodriguez, C. J., Rosamond, W., Sorlie,P. D., Stein, J., Towfighi, A., Turan, T. N., Virani, S. S., Woo, D., Yeh, R. W., \& Turner, M. B. (2016). Heart disease and stroke statistics-2016. Circulation, 133(4), e38-e360.

[5] Riley, L., \& Cowan, M. (2014). Noncommunicable diseases country profiles. World Health Organization. http://apps.who.int/iris/bitstream /10665/128038/1/9789241507509_eng.pdf. Accessed 23 August 2017.

[6] Iqbal, J., Gunn, J., \& Serruys, P. W. (2013). Coronary stents: Historical development, current status and future directions. British Medical Bulletin, 106(1), 193-211.

[7] Joner, M., Finn, A. V., Farb, A., Mont, E. K., Kolodgie, F. D., Ladich, E., Kutys, R., Skorija, K., Gold, H. K., \& Virmani R. (2006). Pathology of drug-eluting stents in humans: delayed healing and late thrombotic risk. Journal of the American College of Cardiology, 48(1), 193-202.

[8] Alicea, L. A., Aviles, J. I., López, I. A., Mulero, L. E., \& Sánchez, L. A. (2004). Mechanics biomaterials: Stents. Applications of Engineering Mechanics in Medicine, F1-F21.

[9] Rhoades, R., \& Bell, D. R. (2009). Medical physiology: Principles for clinical medicine. Pennsylvania: Lippincott Williams \& Wilkins.

[10] Iaizzo, P. A. (2010). Handbook of cardiac anatomy, physiology, and devices. New York: Humana Press.

[11] Kim, J. M., Bae, I. -H., Lim, K. S., Park, J. -K., Park, D. S., Lee, S. -Y., Jang, E. -J., Ji, M. S., Sim, D. S., Hong, Y. J., Ahn, Y., Park, J. C., Cho, J. G., Kang, J. C., \& Jeong, M.H. (2015). A method for coating fucoidan onto bare metal stent and in vivo evaluation. Progress in Organic Coating. $78,348-356$.

[12]Foerst, J., Vorpahl, M., Engelhardt, M., Koehler, T., Tiroch, K., \& Wessely, R. (2013). Evolution of coronary stents: From bare-metal stents to fully biodegradable, drug-eluting stents. Combination Products in Therapy, 3(1), 9-24.

[13] Bhatia, S. K. (2010). Biomaterials for clinical applications. New York: Springer New York.

[14] Garg, S., \& Serruys, P. W. Coronary stents current status. Journal of the American College of Cardiology, 56(10s1), S1-S42.

[15] Grüntzig, A. (1978). Transluminal dilatation of coronary-Artery stenosis. The Lancet, 311(8058), 263.

[16] Byrne, R. A., Joner, M., \& Kastrati, A. (2015). Stent thrombosis and restenosis: what have we learned and where are we going? The Andreas Grüntzig Lecture ESC 2014. European Heart Journal, 36(47), 3320-3331.

[17] Sigwart, U., Puel, J., Mirkovitch, V., Joffre, F., \& Kappenberger, L. (1987). Intravascular stents to prevent occlusion and re-stenosis after transluminal angioplasty. The New England Journal of Medicine, 316(12), 701-706.

[18]Hamid, H., \& Coltart, J. (2007). 'Miracle stents' - A future without restenosis. McGill Journal of Medicine, 10(2), 105-111.

[19] Petrini, L., Wu, W., Gastaldi, D., Altornare, L., Farè, S., Migliavacca, F., Demir, A. G., Previtali, B., \& Vedani, M. (2014). Development of biodegradable magnesium alloy stents with coating. Fracture and Structural Integrity, 29, 364-375.

[20] White, C. J. (2005). Drug-eluting stents: Advanced applications for the management of coronary disease. Florida: CRC Press.

[21] Moses, J. W., Leon, M. B., Popma, J. J., Fitzgerald, P. J., Holmes, D. R., O'Shaughnessy, C., Caputo, R. P., Kereiakes, D. J., Williams, D. O., Teirsten, P. S., Jaeger, J. L., \& Kuntz, R. E. (2003). Sirolimus-eluting 
stents versus standard stents in patients with stenosis in a native coronary artery. The New England Journal of Medicine, 349(14), 1315-1323.

[22] Vlodaver, Z., Wilson, R. F., \& Garry, D. J. (2012). Coronary heart disease: Clinical, pathological, imaging, and molecular profiles. New York: Springer US.

[23] Babapulle, M. N., Joseph, L., Bélisle, P., Brophy, J. M., \& Eisenberg, M. J. (2004). A hierarchical Bayesian meta-analysis of randomised clinical trials of drug-eluting stents. The Lancet, 364(9434), 583-591.23.

[24] Gandhi, P. J., \& Murthy, Z. V. P. (2012). Investigation of different drug deposition techniques on drug releasing properties of cardiovascular drug coated balloons. Industrial \& Engineering Chemistry Research, 51(33), 10800-10823.

[25]Zamani, M., Prabhakaran, M. P., Varshosaz, J., Mhaisalkar, P. S., \& Ramakrishna, S. (2016). Electrosprayed montelukast/poly (lactic-coglycolic acid) particle based coating: A new therapeutic approach towards the prevention of in-stent restenosis. Acta Biomaterialia, 42, 316-328.

[26] Charpentier, E., Barna, A., Guillevin, L., \& Juliard, J. M. (2015). Fully bioresorbable drug-eluting coronary scaffolds: A review. Archives of Cardiovascular Diseases, 108(6-7), 385-397.

[27] Schurtz, G., Delhaye, C., Hurt, C., Thieuleux, H., \& Lemesle, G. (2014). Biodegradable polymer Biolimus-eluting stent (Nobori $\left.{ }^{\circledR}\right)$ for the treatment of coronary artery lesions: review of concept and clinical results. Medical Devices (Auckland), 7, 35-43.

[28] Kim, S. A., \& Lim, S. Y. (2011). A case of stent thrombosis occurred at 5 Years after sirolimus-eluting stent implantation. Chonnam Medical Journal, 47(2), 124-126.

[29]Hermawan, H. (2018). Updates on the research and development of absorbable metals for biomedical applications. Progress in Biomaterials, $7(2), 93-110$.

[30] Soares, J. S., \& Moore, J. E. (2016). Biomechanical challenges to polymeric biodegradable stents. Annals of Biomedical Engineering, 44(2), $560-579$.

[31]Wang, Y., \& Zhang, X. (2014). Vascular restoration therapy and bioresorbable vascular scaffold. Regenerative Biomaterials, 1(1), 49-55.

[32] Bowen, P. K., Shearier, E. R., Zhao S., Guillory, R. J., Zhao, F., Goldman, J., \& Drelich, J. W. (2016). Biodegradable metals for cardiovascular stents: from clinical concerns to recent $\mathrm{Zn}$ - alloys. Advanced Healthcare Materials, 5(10), 1121-1140.

[33] Wan, P., Wu, J., Tan, L., Zhang, B., \& Yang, K. (2013). Research on super-hydrophobic surface of biodegradable magnesium alloys used for vascular stents. Materials Science and Engineering:C, 33(5), 2885-2890.

[34] Waksman, R. O. N., Pakala, R., Baffour, R., Seabron, R., Hellinga, D., \& Tio, F. O. (2008). Short-term effects of biocorrodible iron stents in porcine coronary arteries. Journal of Interventional Cardiology, 21(1), 15-20.

[35]Jiang, W., Tian, Q., Vuong, T., Shashaty, M., Gopez, C., Sanders, T., \& Liu. H. (2017). Comparison study on four biodegradable polymer coatings for controlling magnesium degradation and human endothelial cell adhesion and spreading. ACS Biomaterials Science and Engineering, 3(6), 936-950.

[36]Jensen, L. O., Thayssen, P., Hansen, H. S., Christiansen, E. H., Tilsted, H. H., Krusell, L. R., Villadsen, A. B., Junker, A., Hansen, K. N., Kaltoft, A., Maeng, M., Pedersen, K. E., Kristensen, S. D., Bøtker, H. E. Ravkilde, J., Sanchez, R., Aarøe, J., Madsen, M., Sørensen, H. T., Thuesen, L., \& Lassen, J. F. (2012). Randomized comparison of everolimus-eluting and sirolimus-eluting stents in patients treated with percutaneous coronary intervention: Clinical perspective. Circulation, 125(10), 1246-1255.

[37] Kimura, T., Morimoto, T., Natsuaki, M., Shiomi, H. Igarashi, K., Kadota, K, Tanabe, K., Morino, Y., Akasaka, T., Takatsu, Y., Nishikawa, H., Yamamoto, Y., Nakagawa, Y., Hayashi, Y.,Iwabuchi, M., Umeda, H., Kawai, K., Okada, H., Kimura, K., Simonton, C.A., Kozuma, K.; RESET Investigators. (2012). Comparison of everolimus-eluting and sirolimuseluting coronary stents: Clinical perspective. Circulation, 126(10), 12251236.

[38] Camenzind, E., Wijns, W., Mauri, L., Kurowski, V., Parikh, K., Gao, R., Bode, C., Greenwood, J. P., Boersma, E., Vranckx, P., McFadden, E., Serruys, P. W., O'Neil, W. W., Jorissen, B., Van Leeuwen, F., Steg, P. G.; PROTECT Steering Committee and Investigators. (2012). Stent thrombosis and major clinical events at 3 years after zotarolimus-eluting or sirolimus-eluting coronary stent implantation: A randomised, multicentre, open-label, controlled trial. The Lancet, 380(9851), 13961405.

[39] Kedhi, E., Joesoef, K. S., McFadden, E., Wassing, J., van Mieghem, C., Goedhart, D., Smits, P. C. (2010). Second-generation everolimus-eluting and paclitaxel-eluting stents in real-life practice (COMPARE): A randomised trial. The Lancet, 375(9710), 201-209.

[40] Stone, G. W., Rizvi, A., Newman, W., Mastali, K., Wang, J. C., Caputo, R., Doostzadeh, J., Cao, S., Simonton, C. A., Sudhir, K., Lansky, A. J., Cutlip, D. E., Kereiakes, D. J.; SPIRIT IV Investigators. (2010).
Everolimuseluting versus paclitaxel-eluting stents in coronary artery disease. The New England Journal of Medicine, 362(18), 1663-1674.

[41]Lee, S. Y., Bae, I. H., Park, D. S., Jang, E. J., Shim, J. W., Lim, K. S., Park, J. K., Sim, D. S., Jeong, M. H. (2017). Comparison of dextran-based sirolimus-eluting stents and PLA-based sirolimus-eluting stents in vitro and in vivo. Journal of Biomedical Materials Research Part A, 105(1), 301-310.

[42] Simha, V., Qin, S., Shah, P., Smith, B. H., Kremers, W. K., Kushwaha, S., Wang, L., Pereira, N. L. (2016). Sirolimus therapy is associated with elevation in circulating PCSK9 levels in cardiac transplant patients. Journal of Cardiovascular Translational Research, 10(1), 1-7.

[43] Park, D. S., Park, J. K., Jeong, M. H., Bae, I. -H., Lee, S. -Y., Jang, E. J., Lim, K. S., Kim, J. M., Kim, J. H., Hyun, D. Y., Jeong, Y. A., Kim, H. K., Sim, D. S. (2015). Tacrolimus eluting stent with biodegradable polymer is more effective than sirolimus- and everolimus-eluting stent in rabbit iliac artery restenosis model. Macromolecular Research, 23(11), 1034-1041.

[44] Yazdani, S. K., Sheehy, A., Pacetti, S., Rittlemeyer, B., Kolodgie, F. D., \& Virmani, R. (2016). Stent coating integrity of durable and biodegradable coated drug eluting stents. Journal of Interventional Cardiology, 29(5), 483-490.

[45] Stone, G. W., Lansky, A. J., Pocock, S. J., Gersh, B. J., Dangas, G., Wong, S. C., Witzenbichler, B., Guagliumi, G., Peruga, J. Z., Brodie, B. R., Dudek, D., Möckel, M., Ochala, A., Kellock, A., Parise, H., Mehran, R.; HORIZONS-AMI Trial Investigators. (2009). Paclitaxel-eluting stents versus bare-metal stents in acute myocardial infarction. The New England Journal of Medicine, 360(19), 1946-1959.

[46]Jazi, S. M. H., Shafiei, S., Zarkesh-Esfahani, S. H., Vareki, S. M., Javanmard, S. H. (2011). The effects of bare metal versus drug-eluting stent implantation on circulating endothelial cells following percutaneous coronary intervention. Journal of Research in Medical Sciences, 16(5), $605-610$.

[47] Tao, R., Lu, L., Zhang, R., Hu, J., Ni, J., \& Shen, W. (2011). Triptolide inhibits rat vascular smooth muscle cell proliferation and cell cycle progression via attenuation of ERK1/2 and $\mathrm{Rb}$ phosphorylation. Experimental and Molecular Pathology, 90(2), 137-142.

[48]Lee, J. W. Y., Lee, B. S., Lee, J. Y., Ku, H. J., Jeon, S. R., Kim, J. Y., Ban, J. M., Sung, S. H., Shin, H. M., Park, J. E. (2011). The herbal extract HMC05 inhibits neointima formation in balloon-injured rat carotid arteries: Possible therapeutic implications of HMC05. Journal of Ethnopharmacology, 133(1), 168-176.

[49] Karki, R., Jeon, E. R., \& Kim, D. W. (2012). Magnoliae cortex inhibits intimal thickening of carotid artery through modulation of proliferation and migration of vascular smooth muscle cells. Food and Chemical Toxicology, 50(3), 634-640.

[50] Miswan, Z., Lukman, S. K., Abd Majid, F. A., Loke, M. F., Saidin, S., \& Hermawan, H. (2016). Drug eluting coating of ginsenoside Rg1 and $\mathrm{Re}$ incorporated poly(lactic-co-glycolic acid) on stainless steel 316L: Physicochemical and drug release analyses. International Journal of Pharmaceutics, 515(1-2), 460-466.

[51] Nuri, T., Yee, J., Gupta, M., Khan, M., \& Ming, L. (2016). A review of Panax ginseng as an herbal medicine. Archives of Pharmacy Practice, $7(5), 61-65$.

[52] Court, W. E. (2003). Ginseng, the Genus Panax. Florida: CRC Press.

[53]Biswas, T., Mathur, A. K., \& Mathur, A. (2017). A literature update elucidating production of Panax ginsenosides with a special focus on strategies enriching the anti-neoplastic minor ginsenosides in ginseng preparations. Applied Microbiology and Biotechnology, 101(10), 40094032 .

[54] Kim, H. G., Cho, J. H., Yoo, S. R., Lee, J. S., Han, J. M., Lee, N. H., Ahn, Y. C., Son, C. G. (2003). Antifatigue effects of Panax ginseng C.A. Meyer: A randomised, double-blind, placebo-controlled trial. PLoS One, 8(4), e61271-e61294.

[55]Qin, N., Yang, W., Feng, D., Wang, X., Qi, M., Du, T., Sun, H., Wu, S. (2016). Total ginsenosides suppress monocrotaline-induced pulmonary hypertension in rats: involvement of nitric oxide and mitogenactivated protein kinase pathways. Journal of Ginseng Research, 40(3), 285-291.

[56]He, J., Li, \& Y. -L., (2015). Ginsenoside Rg1 downregulates the shear stress induced MCP-1 Expression by inhibiting MAPK signaling pathway. The American Journal of Chinese Medicine, 43(02), 305-317.

[57]Sun, Y., Liu, Y., \& Chen, K. (2016). Roles and mechanisms of ginsenoside in cardiovascular diseases: progress and perspectives. Science China Life Sciences, 59(3), 292-298.

[58] Shi, A. W., Wang, X. B., Lu, F.X., Zhu, M. M., Kong, X. Q., \& Cao, K. J. (2009). Ginsenoside Rg1 promotes endothelial progenitor cell migration and proliferation. Acta Pharmacologica Sinica, 30(3), 299-306.

[59] Jovanovski, E., Bateman, E. A., Bhardwaj, J., Fairgrieve, C., Mucalo, I., Jenkins, A. L., Vuksan, V. (2014). Effect of Rg3-enriched Korean red ginseng (Panax ginseng) on arterial stiffness and blood pressure in healthy 
individuals: a randomized controlled trial. Journal of the American Society of Hypertension, 8(8), 537-541.

[60]Du, J., Cui, C. H., Park, S. C., Kim, J. -K., Yu, H. -S., Jin, F. X., Sun, C., Kim, S. C., Im, W. T. (2014). Identification and characterization of a gnsenoside-transforming $\beta$-glucosidase from Pseudonocardia sp. Gsoil 1536 and its application for enhanced production of minor ginsenoside Rg2(S). PLoS One, 9(6), e96914.

[61]Zu, G., Guo, J., Che, N., Zhou, \& T., Zhang, X. (2016). Protective effects of ginsenoside $\mathrm{Rg} 1$ on intestinal ischemia/reperfusion injury-induced oxidative stress and apoptosis via activation of the Wnt/ $\beta$-catenin pathway. Scientific Reports, 6(38480), 1-10.

[62] Kim, Y. M., Kim, J. H., Kwon, H. M., Lee, D. H., Won, M. H., Kwon, Y G., Kim, Y. M. (2013). Korean Red Ginseng protects endothelial cells from serum-deprived apoptosis by regulating $\mathrm{Bcl}-2$ family protein dynamics and caspase S-nitrosylation. Journal of Ginseng Research, 37(4), 413-424.

[63]Yu, T., Yang, Y., Kwak, Y. S., Song, G. G., Kim, M. Y., Rhee, M. H., Cho, J. Y. (2017). Ginsenoside Rc from Panax ginseng exerts antiinflammatory activity by targeting TANK-binding kinase 1 /interferon regulatory factor-3 and p38/ATF-2. Journal of Ginseng Research, 41(2), $127-133$. 